\title{
Evaluation of Fire Mitigation and Fire Protection in a Cooking Oil Processing Company
}

\section{Evaluasi Penanggulangan Kebakaran dan Proteksi Kebakaran Di Perusahaan Pengolahan Minyak Goreng}

\author{
Dita Rahmawati \\ Department of Occupational Safety and Health, Faculty of Public Health, Universitas Airlangga \\ Campus C Mulyorejo, Surabaya, East Java, 60115 Indonesia
}

\begin{abstract}
Introduction: A fire ever took place in the early 2019 in one of the cooking oil processing companies in Sidoarjo. This is because the company had a storage warehouse of cartons, jerry cans, and plastic packaging,categorized into flammable materials. The flame was suspected from rags that were exposed to spills of cooking oil, oxygen, and heat from direct sunlight and cigarette butts. The research objectives of this study are to study the implementation of fire mitigation unit and also active and passive fire protection facilities in one of the cooking oil processing companies in Sidoarjo. Methods: The study was observational with a cross sectional design and was analyzed descriptively. It evaluated the suitability of the observational data with the Minister of Manpower Decree Number 186 Year 1999, Minister of Public Work Regulation Number 26 Year 2008, and Minister of Manpower and Transmigration Regulation Number 4 Year 1980. The variables consisted of 1 fire mitigation unit, 1 waterway, 34 fire extinguishers, 7 emergency exits, 41 evacuation routes, and 2 assembly points. Data were collected through the observation and document study. Then, the data were presented in a narrative form. Results: $79.2 \%$ of fire mitigation units, $77.6 \%$ of active fire protection facilities, and $57.1 \%$ of passive fire protection facilities in one of the cooking oil processing companies in Sidoarjo are appropriate with the applicable regulations. Conclusion: The fulfillment level of fire mitigation units and active fire protection facilities are high, while the fulfillment level of passive fire protection facilities are moderate.
\end{abstract}

Keywords: active and passive fire protection, evaluation, fire mitigation

\section{ABSTRAK}

Pendahuluan: Kebakaran pernah terjadi pada awal tahun 2019 di salah satu perusahaan pengolahan minyak goreng di Sidoarjo. Hal ini dikarenakan perusahaan mempunyai gudang penyimpanan karton, jerigen, dan plastik kemasan yang termasuk ke dalam kategori bahan mudah terbakar. Kobaran api diduga berasal dari majun yang terkena tumpahan minyak goreng, oksigen, dan panas dari sinar matahari langsung serta puntung rokok. Tujuan penelitian adalah untuk mempelajari penerapan unit penanggulangan kebakaran dan juga sarana proteksi aktif dan pasif kebakaran di salah satu perusahaan pengolahan minyak goreng di Sidoarjo. Metode: Penelitian bersifat observasional dengan desain cross sectional dan dianalisis secara deskriptif. Dilakukan dengan mengevaluasi kesesuaian data hasil observasi dengan Keputusan Menteri Tenaga Kerja Nomor 186 Tahun 1999, Peraturan Menteri Pekerjaan Umum Nomor 26 Tahun 2008, dan Peraturan Menteri Tenaga Kerja dan Transmigrasi Nomor 4 Tahun 1980. Variabel terdiri dari 1 unit penanggulangan kebakaran, 1 jalur air, 34 APAR, 7 pintu keluar darurat, 41 jalur evakuasi, dan 2 titik berkumpul. Data dikumpulkan melalui observasi dan telaah dokumen. Kemudian data disajikan dalam bentuk narasi. Hasil: 79,2\% unit penanggulangan kebakaran, 77,6\% sarana proteksi aktif kebakaran, dan 57,1\% sarana proteksi pasif kebakaran di salah satu perusahaan pengolahan minyak goring di Sidoarjo sesuai dengan peraturan yang berlaku. Simpulan: Tingkat pemenuhan unit penanggulangan kebakaran dan sarana proteksi aktif kebakaran adalah tinggi, sementara tingkat pemenuhan sarana proteksi pasif kebakaran adalah sedang.

Kata kunci: evaluasi, penanggulangan kebakaran, proteksi aktif dan pasif kebakaran

\section{Corresponding Author:}

Dita Rahmawati

Email: dita.rahmawati-2017@fkm.unair.ac.id

Telephone: +6281938103518

\section{INTRODUCTION}

The development of industry in Indonesia has positive impacts on the improvement of workers' welfare. However, it also has negative impacts like 
accidents and occupational diseases. Therefore, there is a need for assurance through safety and health protection for workers. This can be done through the efforts of controlling potential hazards that exist in the workplace in suppressing risks of loss and increasing worker productivity (Minister of Manpower Decree, 2014).

A Fire in a workplace can be detrimental to the company and workers. So, the fire mitigation consisting of adequate fire mitigation units, fire protection facilities, and procedures of fire mitigation that are appropriate with the Ministerial decree is highly needed. This is done so the fire mitigation officers in the workplace can perform their duties effectively (Minister of Manpower Decree, 1999). One of the potential hazards in an industry that is often encountered and $t$ that often inflicts casualties and material losses is a fire, like what happened in one of the cooking oil processing companies in Sidoarjo 2019. A fire can also cause health problems that are caused by thesmoke (Suma'mur, 2009).

Fires have also occurred in various companies, such as a fire in an oil processing plant of PT. Laguna Industri Nusantara, Tangerang which caused 2 critical people and losses up to hundreds of million rupiahs (Wardana, 2018). A fire can occur at anytime and anywhere and is always accompanied by losses, so it can be said that there are many factors that can trigger a fire (Tarwaka, 2016). Industries that use flammable materials have a higher risk of fires than residential and public areas. A fire does not only eliminate the property or life, but it can also interfere with the sustainability of production process, which can cause a greater financial loss (Ramli, 2010). One of the great fire incidents is the high number of fires in the United States during 2018 , accounting for $1,318,500$ cases of fires with 3,655 civilian deaths, 15,200 civilian injuries, and $\$ 25.6$ billion of property losses (National Fire Protection Association, 2019).

In addition, there were around 410 fire accidents in DKI Jakarta from January to October 2019, which was caused by $74.0 \%$ of electrical short circuits, $14.0 \%$ of gas explosions, and $12.0 \%$ of other causes. There were 13,211 people affected by fires with $1.0 \%$ minor injuries, $0.1 \%$ severe or burn injuries, $0.0 \%$ fatality, and $98.9 \%$ survival rates. In total, the losses reached Rp. 143,638315 billion (DKI Jakarta Statistical Service Center, 2019).

A fire also occurred in PT. Surya Sejahtera Metalindo, Tangerang which killed 8 people (Ramli, 2010). Moreover, there was a fire incident in PT.
Kedaung Indah Can, Surabaya in 2018 which also caused losses up to Rp. 20 billion (Romadhon, 2018). Similarly, a Fire once occurred in PT. Indah Kiat Pulp and Paper, Riau that occurred for three days and caused losses up to Rp. 2.5 trillion (Tarwaka, 2012). The number of losses caused by fires such as the various examples above requires companies to do fire prevention and mitigation efforts to minimize and prevent the company's losses. In short, every workplace should create a healthy and safe workplace from fires through prevention, reduction, and extinguishment of fireas well as fire mitigation exercises in the workplace (President of the Republic of Indonesia, 1970).

Through fire mitigation, fires can be prevented through efforts to control energy, procurement of fire protection and rescue means, and the establishment of fire mitigation unit. Specifically, fire mitigation in the workplace consists of active and passive fire protections. One of the types of active fire protection is fire extinguishers. The use of fire extinguishers has become the most immediate and visible effort if compared to other types of active fire protection equipments. So, fire extinguishers must be well managed in the workplace in order to be used optimally (Minister of Manpower Decree, 1999).

The initial observation in one of the cooking oil processing companies in Sidoarjo states that fire incident ever occurred in the early 2019 and has become one of the biggest potential hazards that occured in this workplace. In the previous years, there were also several fire incidents because this company had the storage warehouse of cartons, jerry cans, and plastic packaging that was made from flammable materials. The flame was suspected from rags that were exposed to spills of cooking oil, oxygen, and heat from direct sunlight and cigarette butts. So, the objectives of this research are to study the implementation of fire mitigation unit and also active and passive fire protection facilities in one of the cooking oil processing companies in Sidoarjo.

\section{METHODS}

This research was a descriptive and crosssectional study. It was conducted in one of the cooking oil processing companies in Sidoarjo in August-September 2019. The variables consisted of fire mitigation unit (12 fire extinguish officers, 1 fire mitigation team, 6 fire mitigation unit coordinators, and 1 Occupational Health and Safety (OHS) expert of fire mitigation specialist), active fire protection 
facilities (1 waterway and 34 fire extinguishers), and passive fire protection facilities ( 7 emergency exits, 41 evacuation routes, and 2 assembly points). The types of data that were collected in this study were secondary data from the company data and primary data from the observation of active and passive fire protections. The data that were then analyzed descriptively and evaluated for its suitability with the prevailing regulations.

\section{RESULTS}

\section{Fire Mitigation Unit}

The observation results of fire mitigation unit can be seen in Table 1. Based on Table 1, it is known that $79.2 \%$ of observation results of fire mitigation unit in one of the cooking oil processing companies in Sidoarjo are appropriate with the Minister of Manpower Decree Number 186 (1999). Meanwhile, the remaining $20.8 \%$ are inappropriate.

\section{Fire Extinguish Officers}

The observation results of fire extinguish officer can be seen in Table 2. Based on Table 2, it is known that $77.8 \%$ of observation results of fire extinguish officers in one of the cooking oil processing companies in Sidoarjo are appropriate with the Minister of Manpower Decree Number 186 (1999). While $22.2 \%$ others were inappropriate.

Table 1. The Observation Results of Fire Mitigation Unit in One of the Cooking Oil Processing Companies in Sidoarjo in September 2019

\begin{tabular}{|c|c|c|c|c|c|c|}
\hline \multirow{3}{*}{$\begin{array}{c}\text { Observation } \\
\text { Subject }\end{array}$} & \multicolumn{4}{|c|}{ Observation Result } & \multirow{2}{*}{\multicolumn{2}{|c|}{ Total }} \\
\hline & \multicolumn{2}{|c|}{ Appropriate } & \multicolumn{2}{|c|}{ Inappropriate } & & \\
\hline & $\mathbf{n}$ & $\%$ & $\mathbf{n}$ & $\%$ & $\mathbf{N}$ & $\%$ \\
\hline $\begin{array}{c}\text { Fire } \\
\text { Extinguish } \\
\text { Officer }\end{array}$ & 7.0 & 77.8 & 2.0 & 22.2 & 9.0 & 100.0 \\
\hline $\begin{array}{c}\text { Fire } \\
\text { Mitigation } \\
\text { Team }\end{array}$ & 16.0 & 88.9 & 2.0 & 11.1 & 18.0 & 100.0 \\
\hline $\begin{array}{c}\text { Fire } \\
\text { Mitigation } \\
\text { Unit } \\
\text { Coordinator }\end{array}$ & 8.0 & 80.0 & 2.0 & 20.0 & 10.0 & 100.0 \\
\hline $\begin{array}{l}\text { OHS Expert } \\
\text { of Fire } \\
\text { Mitigation } \\
\text { Specialist }\end{array}$ & 7.0 & 63.6 & 4.0 & 36.4 & 11.0 & 100.0 \\
\hline Total & 38.0 & 79.2 & 10.0 & 20.8 & 48.0 & 100.0 \\
\hline
\end{tabular}

\section{Fire Mitigation Team}

The observation results of fire mitigation team can be seen in Table 3. Based on Table 3, it is known that $88.9 \%$ observation results of fire mitigation team in one of the cooking oil processing companies in Sidoarjo are appropriate with the Minister of Manpower Decree Number 186 (1999). Meanwhile, the remaining $11.1 \%$ are inappropriate.

\section{Fire Mitigation Unit Coordinators}

The observation results of fire mitigation unit coordinators can be seen in Table 4. Based on Table 4 , it is known that $80.0 \%$ of observation results of fire mitigation unit coordinators in one of the cooking oil processing companies in Sidoarjo are appropriate with the Minister of Manpower Decree Number 186 (1999). Meanwhile, the remaining $20.0 \%$ are inappropriate.

\section{Occupational Health and Safety (OHS) Expert of Fire Mitigation Specialist}

The observation results of Occupational Health and Safety (OHS) expert of fire mitigation specialist can be seen in Table 5. Based on table 5 , it is known that $63.6 \%$ of observation results of Occupational Health and Safety (OHS) expert of fire mitigation specialist in one of the cooking oil processing companies in Sidoarjo are appropriate

Table 2. The Observation Results of Fire Extinguish Officers in One of the Cooking Oil Processing Companies in Sidoarjo in September 2019

\begin{tabular}{|c|c|c|}
\hline \multirow{2}{*}{$\begin{array}{c}\text { Observation } \\
\text { Subject }\end{array}$} & \multicolumn{2}{|c|}{ Observation Result } \\
\hline & Appropriate & Inappropriate \\
\hline Total Officer & - & $\begin{array}{l}12 \text { fire extinguish } \\
\text { officers. }\end{array}$ \\
\hline \multirow{4}{*}{ Task } & $\begin{array}{l}\text { Identify and report the } \\
\text { potential fire hazards. } \\
\text { Extinguish fire } \\
\text { immediately at first } \\
\text { level. }\end{array}$ & \multirow{4}{*}{-} \\
\hline & $\begin{array}{l}\text { Evacuate workers and } \\
\text { goods. }\end{array}$ & \\
\hline & $\begin{array}{l}\text { Coordinate with related } \\
\text { agencies. }\end{array}$ & \\
\hline & Secure the workplace. & \\
\hline & $\begin{array}{l}\text { Physically and } \\
\text { spiritually healthy. }\end{array}$ & \multirow[b]{2}{*}{$\begin{array}{l}\text { No education } \\
\text { degree limit. }\end{array}$} \\
\hline Requirement & $\begin{array}{l}\text { Attend a technical } \\
\text { course of fire } \\
\text { mitigation. }\end{array}$ & \\
\hline
\end{tabular}


with the Minister of Manpower Decree Number 186 (1999). Meanwhile, the remaining 36.4\% are inappropriate.

\section{Active Fire Protection Facilities}

The observation results of active fire protection facility can be seen in Table 6 . Based on Table 6 , it is known that $77.6 \%$ of observation results of active fire protection facility in one of the cooking oil processing companies in Sidoarjo are appropriate with the Minister of Public Work

Table 3. The Observation Results of Fire Mitigation Team in One of the Cooking Oil Processing Companies in Sidoarjo in September 2019

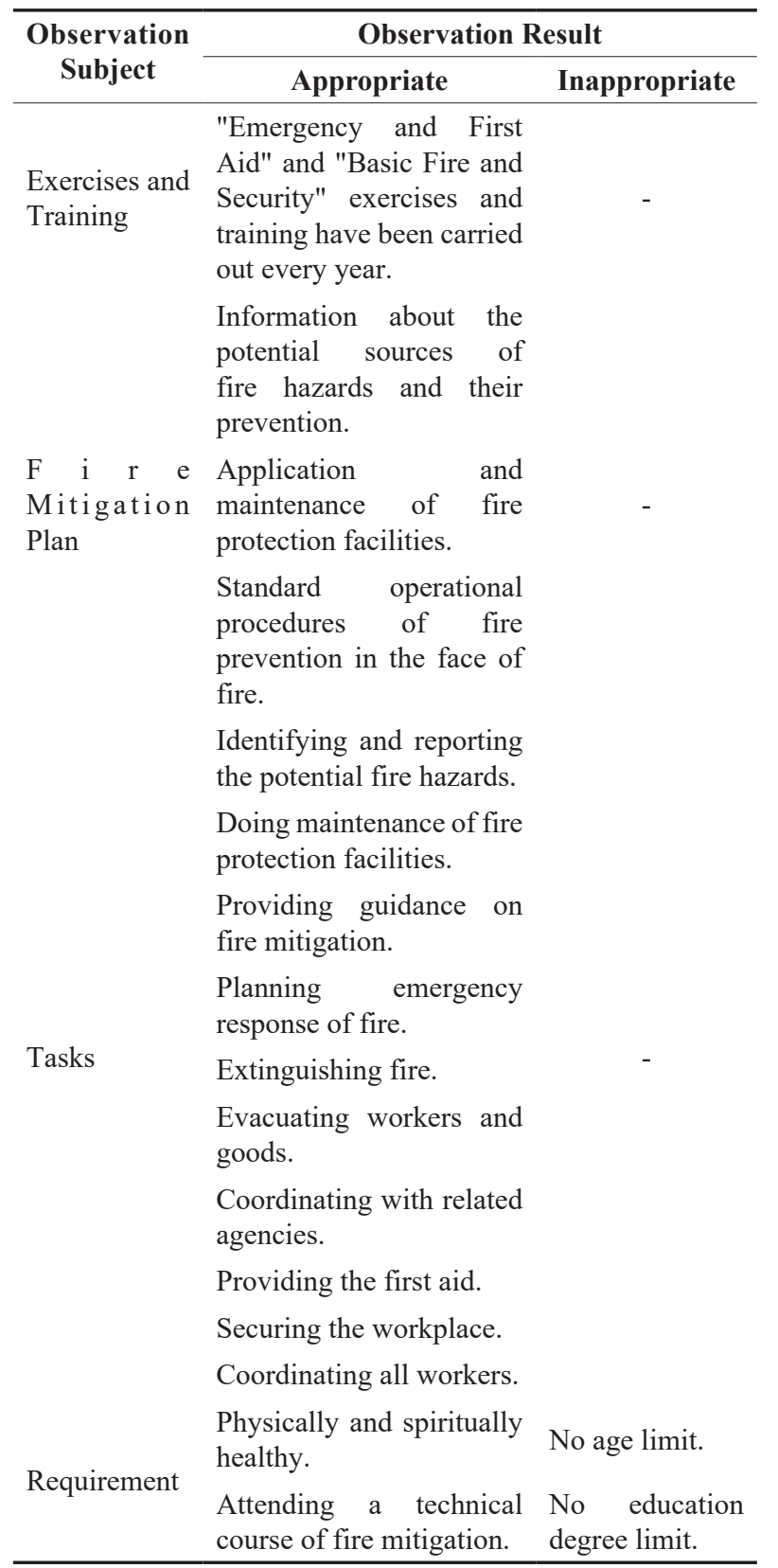

Table 4. The Observation Results of Fire Mitigation Unit Coordinators in One of the Cooking Oil Processing Companies in Sidoarjo in September 2019

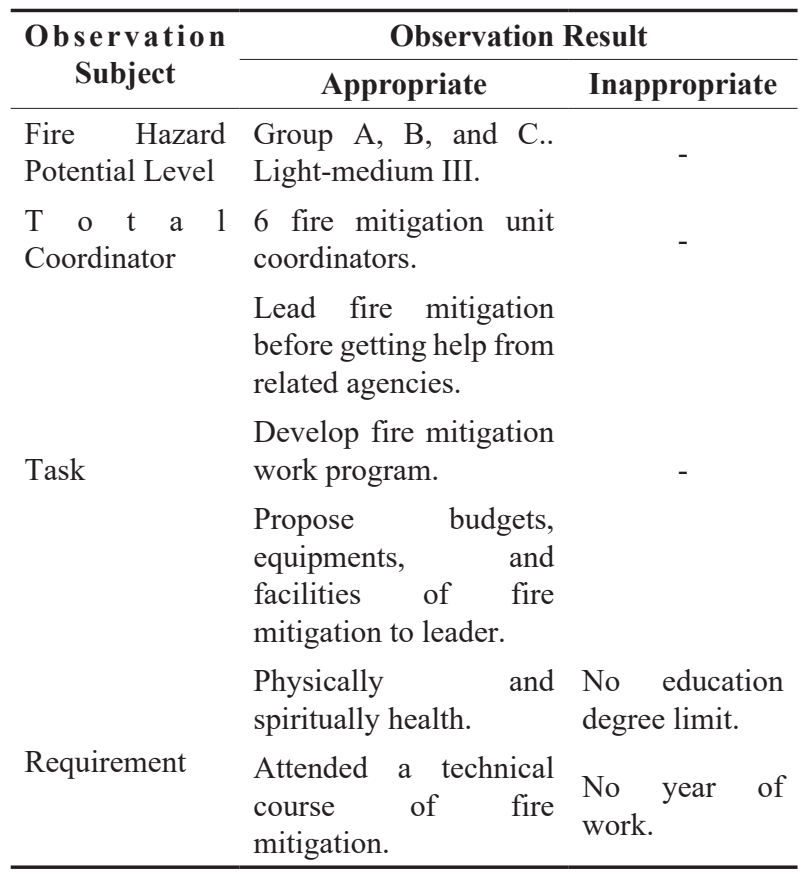

Table 5. The Observation Results of the Occupational Health and Safety (OHS) Expert of Fire Mitigation Specialist in One of the Cooking Oil Processing Companies in Sidoarjo in September 2019

\begin{tabular}{|c|c|c|}
\hline \multirow{2}{*}{$\begin{array}{l}\text { Observation } \\
\text { Subject }\end{array}$} & \multicolumn{2}{|c|}{ Observation Result } \\
\hline & Appropriate & Inappropriate \\
\hline \multirow[t]{3}{*}{ Total Expert } & - & $\begin{array}{l}1 \text { general OHS } \\
\text { experts. }\end{array}$ \\
\hline & $\begin{array}{l}\text { Oversee the fire } \\
\text { mitigation process. }\end{array}$ & - \\
\hline & $\begin{array}{l}\text { Lead fire mitigation } \\
\text { before getting help from } \\
\text { related agencies. }\end{array}$ & \\
\hline \multirow[t]{4}{*}{ Task } & $\begin{array}{l}\text { Develop fire mitigation } \\
\text { work program. }\end{array}$ & \\
\hline & $\begin{array}{l}\text { Propose budgets, } \\
\text { equipment, and facilities } \\
\text { of fire mitigation to } \\
\text { leader. }\end{array}$ & \\
\hline & $\begin{array}{l}\text { Coordinate with related } \\
\text { agencies. }\end{array}$ & \\
\hline & $\begin{array}{l}\text { Physically and } \\
\text { spiritually health. }\end{array}$ & $\begin{array}{l}\text { No education } \\
\text { degree limit. }\end{array}$ \\
\hline \multirow[t]{2}{*}{ Requirement } & $\begin{array}{l}\text { Attended a technical } \\
\text { course of fire } \\
\text { mitigation. }\end{array}$ & No year of work. \\
\hline & & $\begin{array}{l}\text { No appointment } \\
\text { letter. }\end{array}$ \\
\hline
\end{tabular}


Regulation Number 26 (2008) and Minister of Manpower and Transmigration Regulation Number 4 (1980). Meanwhile, the remaining $22.4 \%$ are inappropriate.

\section{Application of Active Fire Protection Facilities}

The observation results of application from active fire protection facilities can be seen in Table 7. Based on Table 7, it is known that $77.4 \%$ of observation results of application from active fire protection facilities in one of the cooking oil processing companies in Sidoarjo are appropriate with the Minister of Public Work Regulation Number 26 (2008) and Minister of Manpower and Transmigration Regulation Number 4 (1980). Meanwhile, the remaining $22.6 \%$ others are inappropriate.

Table 6. The Observation Results of Active Fire Protection Facilities in One of the Cooking Oil Processing Companies in Sidoarjo in September 2019

\begin{tabular}{ccccccc}
\hline \multirow{2}{*}{$\begin{array}{c}\text { Observation } \\
\text { Subject }\end{array}$} & \multicolumn{3}{c}{ Obsevation Result } & \multirow{2}{*}{ Total } \\
\cline { 2 - 6 } & Appropriate & \multicolumn{3}{c}{ Inappropriate } & & \\
\cline { 2 - 7 } & $\mathbf{n}$ & $\%$ & $\mathbf{n}$ & $\mathbf{\%}$ & $\mathbf{N}$ & $\%$ \\
\hline Application & 161.0 & 77.4 & 47.0 & 22.6 & 208.0 & 100.0 \\
Maintenance & 2.0 & 100.0 & 0.0 & 0.0 & 2.0 & 100.0 \\
\hline
\end{tabular}

Table 7. The Observation Results of Application from Active Fire Protection Facilities in One of the Cooking Oil Processing Companies in Sidoarjo in September 2019

\begin{tabular}{|c|c|c|}
\hline \multirow{2}{*}{ Observation Subject } & \multicolumn{2}{|c|}{ Observation Result } \\
\hline & Appropriate & Inappropriate \\
\hline Sprinkler & - & No sprinkler. \\
\hline Waterway & 1 waterway & - \\
\hline Installation Sign & - & 34 pieces \\
\hline $\begin{array}{l}\text { Fire } \\
\text { Access }\end{array}$ & 32 pieces & 2 pieces \\
\hline $\begin{array}{l}\text { Fire Extinguisher } \\
\text { Placement }\end{array}$ & 34 pieces & - \\
\hline Extinguisher & 34 pieces & - \\
\hline $\begin{array}{l}\text { Fire Extinguisher } \\
\text { Condition }\end{array}$ & 33 pieces & 1 piece \\
\hline $\begin{array}{l}\text { Fire } \quad \text { Extinguisher } \\
\text { Height }\end{array}$ & 27 pieces & 7 pieces \\
\hline Fire Alarm & - & No fire alarm. \\
\hline Hydrant & - & 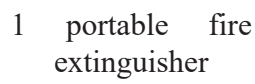 \\
\hline
\end{tabular}

\section{Maintenance of Active Fire Protection Facilities}

The observation results of maintenance from active fire protection facility can be seen in Table 8. Based on Table 8, it is known that $100.0 \%$ of observation results of maintenance from active fire protection facilities in one of the cooking oil processing companies in Sidoarjo are appropriate with the Minister of Manpower and Transmigration Regulation (1980) Number 4 Section 11.

\section{Passive Fire Protection Facilities}

The observation results of passive fire protection facilities can be seen in Table 9. Based on Table 9, it is known that $57.1 \%$ of observation results of

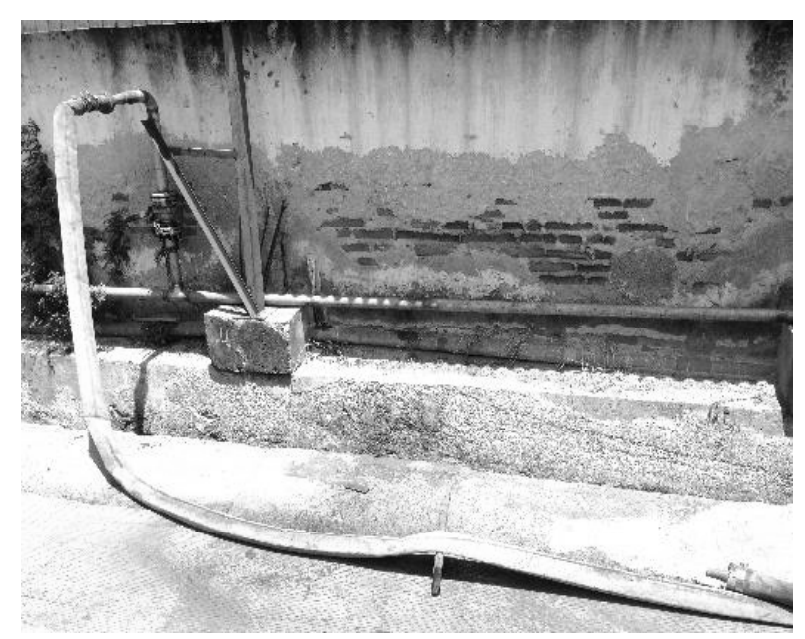

Figure 1. Waterway in the Backyard in September 2019

Table 8. The Observation Results of Maintenance of Active Fire Protection Facilities in One of the Cooking Oil Processing Companies in Sidoarjo in September 2019

\begin{tabular}{llc}
\hline \multirow{2}{*}{$\begin{array}{c}\text { Observation } \\
\text { Subject }\end{array}$} & \multicolumn{2}{c}{ Observation Result } \\
\cline { 2 - 3 } & \multicolumn{1}{c}{ Appropriate } & Inappropriate \\
\hline Schedule & Every month. & - \\
Condition & Replace with a new one. & - \\
\hline
\end{tabular}

Table 9. The Observation Results of Passive Fire Protection Facilities in One of the Cooking Oil Processing

\begin{tabular}{ccccccc}
\hline \multirow{2}{*}{$\begin{array}{c}\text { Observation } \\
\text { Subject }\end{array}$} & \multicolumn{4}{c}{ Obsevation Result } & \multirow{2}{*}{ Total } \\
\cline { 2 - 6 } & Appropriate & \multicolumn{3}{c}{ Inappropriate } & \\
\cline { 2 - 6 } & $\mathbf{n}$ & $\mathbf{\%}$ & $\mathbf{n}$ & $\mathbf{\%}$ & $\mathbf{N}$ & $\%$ \\
\hline Application & 3.0 & 60.0 & 2.0 & 40.0 & 5.0 & 100.0 \\
Maintenance & 1.0 & 50.0 & 1.0 & 50.0 & 2.0 & 100.0 \\
\hline
\end{tabular}


Table 10. The Observation Results of Application of Passive Fire Protection Facilities in One of the Cooking Oil Processing Companies in Sidoarjo in September 2019

\begin{tabular}{lcc}
\hline \multirow{2}{*}{$\begin{array}{c}\text { Obs e rvation } \\
\text { Subject }\end{array}$} & \multicolumn{2}{c}{ Observation Result } \\
\cline { 2 - 3 } & \multicolumn{1}{c}{ Appropriate } & Inappropriate \\
\hline Emergency Exit & 7 emergency exits & - \\
Emergency Stair & - & No emergency stair \\
E m e r g e n c y & - & No emergency \\
Lighting & \multicolumn{3}{c}{ lighting } \\
E v a c u a t i o n & $41 \quad$ evacuation & - \\
Route & routes & \\
Assembly Point & 2 assembly points & - \\
\hline
\end{tabular}

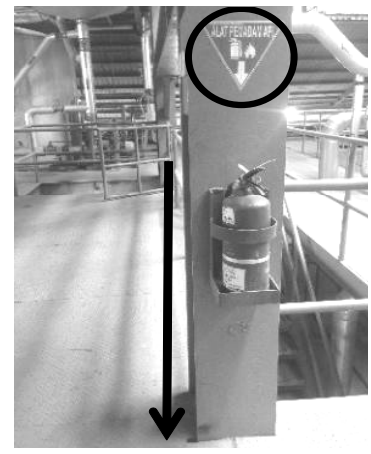

Figure 2. Inappropriate $\mathrm{F}$ i $\mathrm{r}$ e Extinguisher Height and Its Installation Sign on the Polein Refinery in September 2019

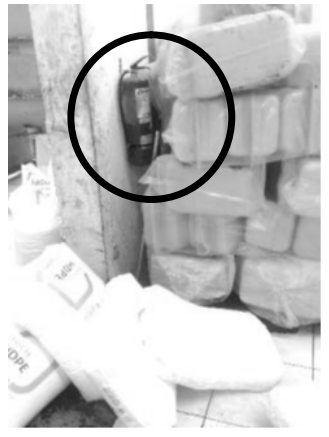

Figure 3. Not Easily Seen and Taken Fire Extinguisher in the Jerry Can Storage Warehouse in September 2019 passive fire protection facility in one of the cooking oil processing companies in Sidoarjo are appropriate with the Minister of Public Work Regulation Number 26 (2008). Meanwhile, the remaining 42.9\% others are inappropriate.

\section{Application of Passive Fire Protection Facilities}

The observation results of application of passive fire protection facility can be seen in Table 10. Based on Table 10, it is known that $60.0 \%$ of observation results of application of passive fire protection facilities in one of the cooking oil processing companies in Sidoarjo are appropriate with the Minister of Public Work Regulation Number 26 (2008). Meanwhile, the remaining $40.0 \%$ are inappropriate.

Table 11. The Observation Results of Maintenance of Passive Fire Protection Facilities in One of the Cooking Oil Processing Companies in Sidoarjo in September 2019

\begin{tabular}{lcc}
\hline Observation & \multicolumn{2}{c}{ Observation Result } \\
\cline { 2 - 3 } Subject & Appropriate & Inappropriate \\
\hline \multirow{2}{*}{ Schedule } & - & No maintenance \\
& & schedule. \\
Condition & Free from any barriers. & - \\
\hline
\end{tabular}

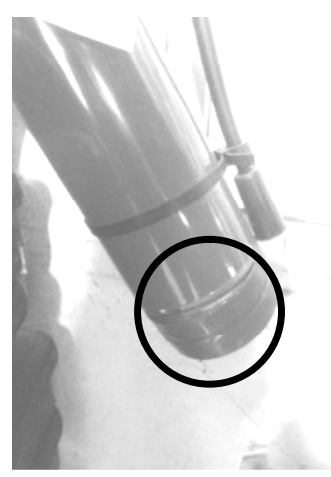

Figure 4. Broken Fire Extinguisher in the Carton $\mathrm{S}$ t o r a g e Warehouse in September 2019

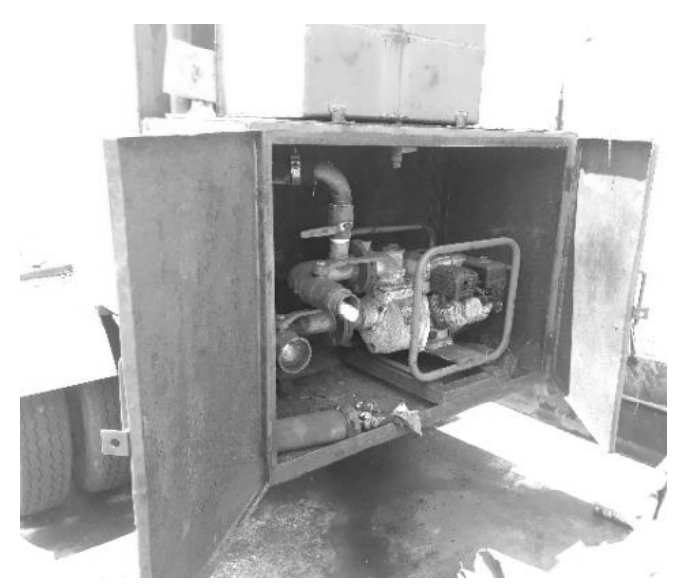

Figure 6. Inappropriate Portable Fire Extinguisher in the Backyard in September 2019

\section{Maintenance of Passive Fire Protection Facilities}

The observation results of maintenance of passive fire protection facilities can be seen in Table 11. Based on Table 11, it is known that $50.0 \%$ of 


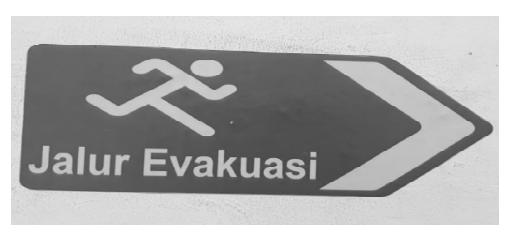

Figure 7. Evacuation Route in the Office in September 2019

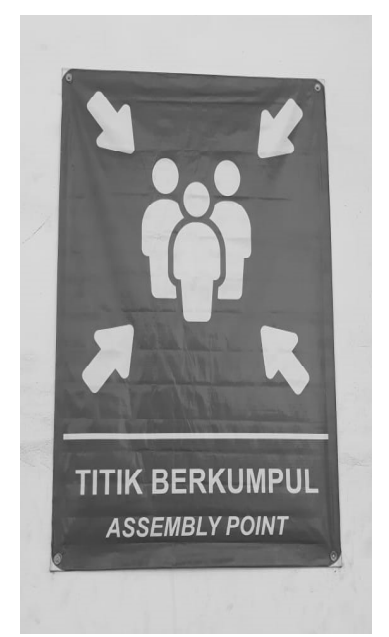

Figure 8. Assembly Point in the Front Yard in September 2019

observation results of maintenance from passive fire protection facilities in one of the cooking oil processing companies in Sidoarjo are appropriate with the Minister of Public Work Regulation Number 26 (2008). Meanwhile, the remaining 50.0\% are inappropriate.

\section{DISCUSSION}

\section{Fire Mitigation Unit}

Based on the Minister of Manpower Decree (1999) Number 186 Section 1, the fire mitigation unit is a working unit that is formed and assigned to deal with the fire mitigation in the workplace. Moreover, based on Section 5, fire mitigation unit consists of fire extinguish officers, fire mitigation team, fire mitigation unit coordinators, and also Occupational Health and Safety (OHS) experts of fire mitigation specialist. But, $20.8 \%$ of observation results of fire mitigation unit in one of the cooking oil processing companies in Sidoarjo are inappropriate with the Minister of Manpower Decree Number 186 (1999).

So, there is a need for some addition and improvement of 7 fire extinguisher officers and 1
Occupational Health and Safety (OHS) expert of fire mitigation specialist, and also a requirement for fire extinguish officers, fire mitigation teams, fire mitigation unit coordinators, and Occupational Health and Safety (OHS) experts of fire mitigation specialists. The fire mitigation unit has responsibility to face fire and has objective to minimize losses and casualties that are caused by fire (Mufida and Martiana, 2019;. The establishment of fire mitigation unit also has a necessity to ensure the worker safety with the right procedures, responses, and actions for fire prevention (Karimah, Kurniawan and Suroto, 2016). On the other hand, fire can also affect the image and trust of stakeholders, which can disrupt company's business activity (Haqi, 2018).

\section{Fire Extinguish Officers}

Based on the Minister of Manpower Decree (1999) Number 186 Section 1, a fire extinguish officer is officer that is appointed and given additional tasks to identify the hazard source and carry out fire mitigation at their workplace. Moreover, based on Section 6, there are at least 2 fire extinguish officers for every 25 workers. Based on Section 7, other tasks of fire extinguish officers are identifying and reporting the potential fire hazards, extinguishing fire immediately at first level, evacuating workers and goods, coordinating with related agencies, and securing the workplace. The requirements to become fire extinguish officers are being physically and spiritually healthy, having a minimum Junior High School education degree, and having attended a technical course of fire mitigation.

However, $22.2 \%$ observation results of fire extinguish officer in one of the cooking oil processing companies in Sidoarjo are inappropriate with the Minister of Manpower Decree Number 186 (1999). The total number of 12 fire extinguish officers have not fulfilled the requirements, suggesting that there should be least 2 officers for every 25 workers. Because the total workers are only 234 , so it requires 19 officers more, or it needs additional 7 officers. Thus, the requirement of no education degree limit is inappropriate with the Minister of Manpower Decree (1999) Number 186 Section 7, suggesting the workers to have a minimum Junior High School education degree. So, this company also needs to improve the requirement of education degree limit (Junior High School) to become a fire extinguish officer. It is expected that with the requirement of education degree limit, all 
officers are able to extinguish fire because the fire extinguish officer must be able to extinguish fire since the beginning (Nugraha, 2018).

\section{Fire Mitigation Team}

Based on the Minister of Manpower Decree (1999) Number 186 Section 1, the fire mitigation team is a team that has specific functional tasks in fire mitigation unit. Moreover, based on Section 2, the company must carry out exercises and training of fire mitigation periodically for fire mitigation team and arrange a fire mitigation plan that consists of information about the potential sources of fire hazards and their prevention, application and maintenance of fire protection facilities, as well as standard operational procedures of fire prevention. Based on Section 8, fire mitigation team has tasks such as identifing and reporting the potential fire hazards, doing maintenance of fire protection facilities, providing guidance on fire mitigation, planning emergency response of fire, extinguishing fire, evacuating workers and goods, coordinating with related agencies, providing the first aid, securing the workplace, and coordinating all workers. Furthermore, the requirements to become fire mitigation team are being physically and spiritually healthy, having a minimum age of 25 years old and maximum age of 45 years old having minimum degree of senior sigh school education degree, and having attended a technical course of fire mitigation.

However, $11.1 \%$ of observation results of fire mitigation team in one of the cooking oil processing companies in Sidoarjo are inappropriate with the Minister of Manpower Decree Number 186 (1999). No requirement forage limit and education degree limit are inappropriate with the Minister of Manpower Decree (1999) Number 186 Section 8 , suggesting the workers to a minimum age of 25 years old and maximum age of 45 years old as well as minimum senior high school education degree. So, this company needs to improve the requirements of age limit ( 25 and 45 years old) and education degree limit (senior high school) to join with the fire mitigation team. A fire can be caused by various factors, but it is often caused by human errors (Lestaluhu and Paskarini, 2019). The requirements to join with fire mitigation team that are set by government will make it easier for team members to understand their duties, authorities, and responsibilities when they face the fire (Pratama, 2016). These preparations also guarantee the worker safety through correct procedures in fire prevention and mitigation (Karimah, Kurniawan and Suroto, 2016). If there are no requirements, it can bring a negative impact when a fire emergency occurs because the company will only rely on person who fulfills the requirements to have the ability to extinguish fire. So, the losses caused by the fire cannot be minimized (Priambudi, Kurnawan, and Widjasena, 2017).

\section{Fire Mitigation Unit Coordinator}

Based on the Minister of Manpower and Transmigration Regulation (1980) Number 4 Section 2, fire can be classified into group A (solid materials except metal), group B (flammable liquid or gas), group $\mathrm{C}$ (electrical installations), and group D (metal). Meanwhile, based on the Minister of Manpower Decree (1999) Number 186 Section 4 , the classifications of fire hazard potential level are light, light-medium I, light-medium II, lightmedium III, and heavy. Moreover, based on Section 6 , the company needs at least 1 fire migitation unit coordinator for workplace with fire hazard potential level of light-medium. Also, based on Section 9, the fire mitigation unit coordinator has tasks to lead fire mitigation before getting help from related agencies, develop fire mitigation work programs, and also propose budgets, equipments, and facilities of fire mitigation to the leader. The requirements to become fire mitigation unit coordinator are being physically and spiritually healthy, having minimum Senior high school education degree, having minimum 5 years of work period, and has attended a technical course of fire mitigation.

However, $20.0 \%$ of observation results of fire mitigation unit coordinators in one of the cooking oil processing companies in Sidoarjo are inappropriate with the Minister of Manpower Decree Number 186 (1999). No requirement for education degree limit and year of work are inappropriate with the Minister of Manpower Decree (1999) Number 186 Section 9, suggesting that workers have minimum senior high school education degree and has minimum 5 years of work. So, this company needs to improve the requirements of education degree limit (senior high school) and 5 years of work period for the workers to become fire mitigation unit coordinator. If there are no requirements, it can bring a negative impact when a fire emergency occurs because it will make fire mitigation unit coordinators difficult to understand their duties, authorities, and responsibilities when they the coordinator are also difficult to understand 
the evacuation routes and workplace condition to evacuate workers and goods. So, this company needs to improve the quality of each fire mitigation unit coordinator (Septiadi, Sunarsih, and Camelia, 2015).

\section{Occupational Health and Safety (OHS) Expert of Fire Mitigation Specialist}

Based on the Minister of Manpower Decree (1999) Number 186 Section 6, the Occupational Health and Safety (OHS) expert of fire mitigation specialist is needed in a workplace with fire hazard potential level of light-medium III. Moreover, based on Section 10, the Occupational Health and Safety (OHS) expert of fire mitigation specialist has tasks to oversee the fire mitigation process; lead fire mitigation before getting help from related agencies; develop fire mitigation work programs; propose budgets, equipment, and facilities of fire mitigation to leader; and also coordinate with related agencies. Besides, the requirements to become the Occupational Health and Safety (OHS) expert of fire mitigation specialist are physically and spiritually healthy, has minimum D3 Engineering education degree, has a minimum of 5 years of work period, has attended a technical course of fire mitigation, and has an appointment letter from the concerned ministry.

Nevertheless, $36.4 \%$ of observation results of Occupational Health and Safety (OHS) expert of fire mitigation specialist in one of the cooking oil processing companies in Sidoarjo are inappropriate with the Minister of Manpower Decree Number 186 (1999). The total number of 1 general Occupational Health and Safety (OHS) expert is inappropriate with the Minister of Manpower Decree (1999) Number 186 Section 6, suggesting that there should be 1 Occupational Health and Safety (OHS) expert of fire mitigation specialist for workplace with fire hazard potential level of light-medium III. No requirements for education degree limit, no year of work, and no appointment letter are inappropriate with Minister of Manpower Decree (1999) Number 186 Section 10, suggesting that workers should have minimum D3 Engineering education degree, minimum 5 years of work, and an appointment letter from the concerned ministry. This company does not have Occupational Health and Safety (OHS) experts of fire mitigation specialist, so this task is carried out by the Occupational Health and Safety (OHS) staff. Thus, this company needs to add 1 Occupational Health and Safety (OHS) expert of fire mitigation specialist that has minimum D3 Engineering education degree, has minimum 5 years of work, and has an appointment letter from the concerned ministry.

\section{Active Fire Protection Facilities}

Based on the Minister of Manpower Decree (1999) Number 186 Section 1, procurement of fire protection facility is a form of fire mitigation effort. However, 22.4\% observation results of active fire protection facilities in one of the cooking oil processing companies in Sidoarjo are inappropriate with the Minister of Public Work Regulation Number 26 (2008) and Minister of Manpower and Transmigration Regulation Number 4 (1980). So, the company needs some addition and improvement of application of active fire protection facilities like sprinklers, fire alarms, hydrants, fire extinguisher installation signs, and also fire extinguisher access, condition, and height. The application and maintenance of active fire protection facilities have been made to facilitate and maintain the quality of active fire protection facilities (Pratama, 2016). For example, the unavailability of fire alarm can be detrimental to the company in the long term because a fire alarm works automatically to notify a hazard that is previously detected by a fire detector (Kowara and Martiana, 2017).

\section{Application of Active Fire Protection Facilities}

Based on the Minister of Public Work Regulation (2008) Number 26 Section 1, an active fire protection facility is a complete fire protection facility that consists of manual or automatic fire protection system like sprinklers, waterways, fire extinguishers, fire alarms, and hydrants. Moreover, based on the Minister of Manpower and Transmigration Regulation (1980) Number 4 Section 4 , fire extinguishers must be placed in a position that is easily seen and taken, and is also equipped with a fire extinguisher installation sign. The sign that is placed on the wall should use an equilateral triangle in a red base color, and should have the side lengthof $35 \mathrm{~cm}$, letter height of $3 \mathrm{~cm}$ in white color, and arrow height of $7.5 \mathrm{~cm}$ in white color. Meanwhile, for the fire extinguisher, the installation of the sign that is placed on a pole should use a red base color with $20 \mathrm{~cm}$ in width and is mounted circling the pole.

Morover, the height of fire extinguisher installation sign is $125 \mathrm{~cm}$ between the top of the fire extinguisher and the floor surface. In addition, 
fire extinguisher installation and placement should be appropriate with the type and classification of fire. The placement of one fire extinguisher with another may not exceed 15 meters, as specified or recommended by the Occupational Health and Safety (OHS) experts. Also, all of fire extinguisher tubes should be red. Moreover, based on Section 5 , it is not allowed to $t$ install and use broken fire extinguishers. Section 8 further suggests thatthe fire extinguishers should be installed in height of $120 \mathrm{~cm}$ from the floor surface, except for $\mathrm{CO} 2$ gas and dry chemical powder type which can be placed lower with the distance between the base of the fire extinguisher and floor surface not less than $15 \mathrm{~cm}$.

However, $22.6 \%$ of observation results of application from active fire protection facilities in one of the cooking oil processing companies in Sidoarjo are inappropriate with the Minister of Public Work Regulation Number 26 (2008) and Minister of Manpower and Transmigration Regulation Number 4 (1980). No provision of a sprinkler and afire alarm, and only 1 portable fire extinguisher are inappropriate with the Minister of Public Work Regulation (2008) Number 26 Section 1, suggesting that active fire protection facilities should consist of sprinklers, fire alarms, hydrants, and others. Fire alarm is used to provide information to all workers when a fire occurs. So, the evacuation and fire mitigation process become easier (Miranti and Mardiana, 2018). Besides, 34 pieces of sign installation of fire extinguishers (23 sign installations on the wall and 11 sign installations on the pole) are inappropriate with the Minister of Manpower and Transmigration Regulation (1980) Number 4 Section 4, suggesting that the sign installation of fire extinguishers that is placed on the wall should havethe side length of $35 \mathrm{~cm}$, while the sign that is placed on the pole should be mounted circling the pole, and also have $125 \mathrm{~cm}$ in height with floor surface.

Moreover, 2 pieces of fire extinguisher access that are covered with cardboards and jerry cans are inappropriate with the sMinister of Manpower and Transmigration Regulation (1980) Number 4 Section 4, suggesting that an active fire extinguisher must be placed in a position that is easily seen and taken. Also, 1 piece of fire extinguisher condition that is exposed to forklifts is inappropriate with the Minister of Manpower and Transmigration Regulation (1980) Number 4 Section 5, suggesting not to install and use broken fire extinguishers. Meanwhile, 7 pieces of fire extinguisher height
( 2 pieces of $\mathrm{CO} 2$ gas type and 4 pieces of dry chemical powder type) are placed in height of $>$ $120 \mathrm{~cm}$, and 1 piece of dry chemical powder type is placed in height of $<15 \mathrm{~cm}$ ) are inappropriate with the Minister of Manpower and Transmigration Regulation (1980) Number 4 Section 8, suggesting that the fire extinguisher should be installed with the height of $120 \mathrm{~cm}$ from the floor surface, except for $\mathrm{CO} 2$ gas and dry chemical powder type which can be placed lower with the distance between the base of fire extinguisher and floor surface not less than $15 \mathrm{~cm}$.

So, there is a need for some addition and improvement of sprinklers, fire alarms, hydrants, fire extinguisher installation signs, and also good control of fire extinguisher access, condition, and height. If the active fire protection facilities do not fulfill the standards, it can cause loss and even death (Hambyah, 2016). The fire extinguisher condition is also very influential on the feasibility of when to use it; if the fire extinguisher is in good condition then the risk of a greater fire can be overcome quickly (Firdani, Ekawati and Kurniawan, 2014). Furthermore, the fire extinguisher installation sign that is hard to find can also increase time to find the fire extinguisher (Romadhon, 2018).

In addition, the fire extinguisher with a damaged condition will not have an appropriate performance, and the material inside becomes malfunction. There is also a pressure drop that can make fire extinguisher unable to reach the fire, and the extinguishing fire process becomes ineffective. Moreover, it is also feared that the fire extinguisher access and height with inappropriate conditions will make fire extinguish officers difficult to take the fire extinguishers in fire condition which can occur at any time (Hambyah, 2016). If an emergency occurs and the components do not meet the standards, the consequences will be fatal (Sanjaya and Ulfa, 2019). Fire extinguishers that are ready to use are also influenced by their installation (Lestaluhu and Paskarini, 2019).

\section{Maintenance of Active Fire Protection Facility}

Based on the Minister of Manpower and Transmigration Regulation (1980) Number 4 Section 11 , the provisions of fire extinguisher inspection has been done every 6 or 12 months or only 2 times or once a year. Moreover, the broken fire extinguishers should be repaired or replaced with the new ones. $100.0 \%$ of observation results of maintenance from active fire protection facilities in one of the cooking 
oil processing companies in Sidoarjo are appropriate with the Minister of Manpower and Transmigration Regulation (1980) Number 4 Section 11. The maintenance of active fire protection facilities such as periodical fire extinguisher inspection has been done very well by this company. Besides, the inspection has been conducted every month (12 times a year). The management also needs to monitor and evaluate the maintenance of active fire protection facility programs regularly so that the programs can run efficiently and effectively (Muchtar, Ibrahim and Raodhah, 2016).

Meanwhile, based on the Minister of Manpower and Transmigration Regulation (1980), the provisions of fire extinguisher inspection have been done every 6 or 12 months or only 2 times or once in a year. if the fire extinguishers do not fulfill the standards, it can cause loss and even death (Hambyah, 2016). The maintenance of broken fire extinguishers has been carried out by replacing them with the new ones. This action isin accordance with the Minister of Manpower and Transmigration Regulation number 4 year 1980, which states that the broken fire extinguishers should be repaired or replaced with the new ones. In addition, the fire extinguisher that approaches the expiration date will be refilled or replaced by the third third parties, namely CV. Bayu Putra Satria and CV. Carolina Perdana.

\section{Passive Fire Protection Facility}

Based on the Minister of Manpower Decree (1999) Number 186 Section 1, the procurement of evacuation facility is a form of fire mitigation effort. However, $42.9 \%$ of observation results of passive fire protection facilities in one of the cooking oil processing companies in Sidoarjo are inappropriate with the Minister of Public Work Regulation Number 26 (2008). So, the company need some addition and improvement of the application and maintenance from passive fire protection facilities like emergency exits, emergency stairs, emergency lighting, and maintenance schedule. Passive fire protection facilities must fulfill the standards that allow workers to save themselves quickly and securely (Pratama, 2016) before fire threatens their lives in a short time (Maharani, Fitri and Buntara, 2019). This passive fire protection facilities actually play an important role when a fire happens, but the observation results of passive fire protection facilities show that they are still not implemented optimally to improve fire propagation in company's buildings (Kowara and Martiana, 2017).

\section{Application of Passive Fire Protection Facilities}

Based on the Minister of Public Work Regulation (2008) Number 26 Section 1, a passive fire protection facility is facility that is prepared for occupants or fire extinguish officers to save lives and property in fire condition, consisting of emergency exits, emergency stairs, emergency lights, evacuation routes, and assembly points. However, $40.0 \%$ of observation results of application from passive fire protection facilities in one of the cooking oil processing companies in Sidoarjo are inappropriate with Minister of Public Work Regulation Number 26 (2008).

No provision of an emergency stair and emergency lighting are inappropriate with the Minister of Public Work Regulation (2008) Number 26 Section 1, suggesting that passive fire protection facilities should consist of emergency exits, emergency stairs, emergency lighting, evacuation routes, and assembly points to save lives and property in fire condition. So, the company needs some addition and improvement of application from passive fire protection facilities like emergency exits, emergency stairs, and emergency lighting. The passive fire protection facilities must fulfill the requirements that allow workers to save themselves quickly and securely (Pratama, 2016). Besides, the passive fire protection facilities must allow all workers to vacate the building safely before fire threatens their lives in a short time (Maharani, Fitri and Buntara, 2019).

\section{Maintenance of Passive Fire Protection Facility}

Based on the Minister of Public Work Regulation (2008) Number 26 Chapter 3, passive fire protection facilities must be maintained continuously and free from any barriers. However, $50.0 \%$ of observation results of maintenance from passive fire protection facilities in one of the cooking oil processing companies in Sidoarjo are inappropriate with the Minister of Public Work Regulation Number 26 (2008). NO provision of maintenance schedule is inappropriate with the Minister of Public Work Regulation (2008) Number 26 Chapter 3, suggesting that passive fire protection facilities must be maintained continuously.

This is one way to improve fire safety management in a sustainable community. It is also 
necessary to always keep fire safety at a good level and avoid damage to a fire safety management system. With a continuous improvement, a community can know when there is a mismatch in the fire safety management system and can immediately take actions to overcome it to maintain the safety level of the community's fire safety (Kuntoro, 2017). Thus, it is clear that the appropriate condition of passive fire protection facilities can prevent accidents during evacuation process (Nugraha, 2018). Every building that is equipped with a well-maintained passive fire protection facility can also be used by building occupants to escape safely (Mufida and Martiana, 2019). Therefore, the company needs passive fire protection facilities that are maintained continuously.

\section{CONCLUSION}

Based on research in one of the cooking oil processing companies in Sidoarjo, it can be concluded that $79.2 \%$ of fulfillments of fire mitigation unit have been met with high level, $77.6 \%$ fulfillments of active fire protection facilities have been met with high level, and $57.1 \%$ fulfillments of passive fire protection facilities have been met with moderate level. So, there is a need for the addition and improvement of some fire mitigation unit, including 7 fire extinguisher officers and 1 Occupational Health and Safety (OHS) expert of fire mitigation specialist. And also requirements of fire extinguisher officers, fire mitigation teams, fire mitigation unit coordinators, and Occupational Health and Safety (OHS) experts of fire mitigation specialists. Moreover, there a is also a need for some addition and improvement of active fire protection facilities like sprinklers, fire alarms, hydrants, fire extinguisher installation sign, and also good control of fire extinguisher access, condition, and height. Furthermore, there also is also a need for the addition and improvement of some passive fire protection facilities like emergency exits, emergency stairs, emergency lighting, and maintenance schedule.

\section{ACKNOWLEDGEMENTS}

This research is fully self-funded. The author would like to thank the leader, staff, and workers of the cooking oil processing company in Sidoarjo as well as other parties that have helped in the accomplishment of this research.

\section{REFERENCES}

DKI Jakarta Statistical Service Center (2019) Fire Incident along with The Number of Losses, Casualties, and Their Causes in 2019. Jakarta: The Jakarta Provincial Government in The Communication, Informatics, and Statistics Department.

Firdani, L., Ekawati and Kurniawan, B. (2014) 'Analysis of the Application of Light Fire Extinguisher at PT. X Pekalongan', , 2(5), pp. 300-308.

Hambyah, R. F. (2016) 'Evaluation of APAR Installation in The Fire Emergency Response System in The Surgical Hospital Dr. Soetomo Surabaya', The Indonesian Journal of Occupational Safety and Health, 5(1), pp. 41-50.

Haqi, D. N. (2018) 'Hazardous Potential and Risk Analysis of Fire and Explosion in LPG Storage Tank Pertamina Perak Surabaya', The Indonesian Journal of Occupational Safety and Health, 7(3), pp. 321-328.

Karimah, M., Kurniawan, B. and Suroto. (2016) 'Analysis of Fire Fighting Efforts at Bougenville Building Telogorejo Hospital Semarang', Jurnal Kesehatan Masyarakat, 4(4), pp. 698-706.

Kowara, R. A. and Martiana, T. (2017) 'Analysis of Fire Protection System as Fire Prevention and Mitigation Effort (Case Study in PT. PJB UP Brantas Malang)', Jurnal Manajemen Kesehatan, 3(1), pp. 70-85.

Kuntoro, C. (2017) 'Implementation of Fire Risk Management Based on (IS) ISO 31000 PT APAC Inti Corpora', Higeia Journal of Public Health Research and Development, 1(4), pp. 109-119.

President of the Republic of Indonesia (1970) Law of Republic of Indonesia Number 1 Year 1970 tentang Keselamatan Kerja. Jakarta: Department of Law and Legislation Republic of Indonesia.

Lestaluhu, F. and Paskarini, I. (2019) 'Installation Fire Extinguisher in PT. E-T-A Indonesia', The Indonesian Journal of Occupational Safety and Health, 8(1), pp. 38-46.

Maharani, F. T., Fitri, A. M. and Buntara, A. (2019) 'The Analysis of Fire Engineering and Administrative Control at Building X University Y Year 2018', The Indonesian Journal of Occupational Safety and Health, 8(1), pp. 57-65.

Minister of Manpower and Transmigration Regulation (1980) Number 4 Year 1980. Terms of Installation and Maintenance of Fire Extinguisher. Jakarta: 
Ministry of Manpower and Transmigration Republic of Indonesia.

Minister of Manpower Decree (1999) Number 186 Year 1999. Fire Mitigation Unit in Workplace. Jakarta: Ministry of Manpower Republic of Indonesia.

Minister of Manpower Decree (2014) Number 386 Year 2014. Instructions for Implementation of National Occupational Health and Safety in 20152019. Jakarta: Ministry of Manpower Republic of Indonesia.

Minister of Public Work Regulation (2008) Number 26 Year 2008. Technical Requirements of Fire Protection Systems in Buildings and Environment. Jakarta: Ministry of Public Work Republic of Indonesia.

Miranti, R. S. and Mardiana. (2018) 'Application of Active Protection System and Fire Rescue as Fire Rescue Preventing Action', Higeia Journal of Public Health Research and Development, 2(1), pp. 12-22.

Muchtar, H. K., Ibrahim, H. and Raodhah, S. (2016) 'Efficiency and Effectiveness Analysis of Fire Safety Management Implementation in Fire Prevention Efforts at PT. Consolidaetd Electric Power Asia (Cepa), Wajo Regency', Higiene: Jurnal Kesehatan Lingkungan, 2(2), pp. 91-98.

Mufida, M. R. and Martiana, T. (2019) 'Fire Emergency Response System in Administration Building Electrical Industry', The Indonesian Journal of Occupational Safety and Health, 8(1), pp. 47-56.

National Fire Protection Association (2019) Fire Loss in the United States During 2018. Quincy: National Fire Protection Association.

Nugraha, R. (2018) 'Application of Fire Management System in PT. Adiluhung Saranasegara Indonesia, Bangkalan', The Indonesian Journal of Occupational Safety and Health, 7(3), pp. 378-386.
Pratama, A. (2016) 'Design of Self-Rescue Facilities and APAR Needs in Fire Emergency in Health Office of Class II Port Balikpapan', The Indonesian Journal of Occupational Safety and Health, 5(1), pp. 21-30.

Priambudi, B. S., Kurnawan, B. and Widjasena, B. (2017) 'The Management's Readiness Against Conditions Fire Emergency at PT. X (Pulp \& Paper) 2017', Jurnal Kesehatan Masyarakat, 5(5), pp. 336-345.

Ramli, S. (2010) Fire Management Practical Instructions. Jakarta: Dian Rakyat.

Romadhon, B. (2018) 'Fire Protection Analysis on Gas Production Company and Power Plant', The Indonesian Journal of Occupational Safety and Health, 7(2), pp. 142-151.

Sanjaya, M. and Ulfa, M. (2015) 'Evaluation of Hospital Facilities And Infrastructure In Dealing With Fire Disaster (Case Study in PKU Muhammadiyah Yogyakarta Unit II Hospital)', Jurnal Medicoeticological dan Manajemen Rumah Sakit, 4(2), pp. 1-20.

Septiadi, H., Sunarsih, E. and Camelia, A. (2015) 'Fire Protection System Analysis at Building and Environment in Inderalaya Campus of Sriwijaya University', Jurnal Ilmu Kesehatan Masyarakat, $5(1)$, pp. 49-56.

Suma'mur (2009) Corporate Hygiene and Occupational Health. Jakarta: Sagung Seto.

Tarwaka (2012) The Basics of Occupational Safety and Accident Prevention at Workplace. Surakarta: Harapan Press.

Tarwaka (2016) The Basis of Work Safety and Accident Prevention at Workplace. Surakarta: Harapan Press.

Wardana, R. P. (2018) 'Evaluation of Installation and Maintenance of Portable Fire Extinguisher in Gresik', The Indonesian Journal of Occupational Safety and Health, 7(3), pp. 261-272. 